\title{
In vitro antiplasmodial, antileishmanial and antitrypanosomal activities of selected medicinal plants used in the traditional Arabian Peninsular region
}

\author{
Nawal M Al-Musayeib', Ramzi A Mothana ${ }^{1 *}$, An Matheeussen², Paul $\operatorname{Cos}^{2}$ and Louis Maes²
}

\begin{abstract}
Background: Worldwide particularly in developing countries, a large proportion of the population is at risk for tropical parasitic diseases. Several medicinal plants are still used traditionally against protozoal infections in Yemen and Saudi Arabia. Thus the present study investigated the in vitro antiprotozoal activity of twenty-five plants collected from the Arabian Peninsula.

Methods: Plant materials were extracted with methanol and screened in vitro against erythrocytic schizonts of Plasmodium falciparum, intracellular amastigotes of Leishmania infantum and Trypanosoma cruzi and free trypomastigotes of T. brucei. Cytotoxic activity was determined against MRC-5 cells to assess selectivity. The criterion for activity was an $\mathrm{IC}_{50}<10 \mu \mathrm{g} / \mathrm{ml}(<5 \mu \mathrm{g} / \mathrm{ml}$ for $\mathrm{T}$. brucei) and selectivity index of $>4$.

Results: Antiplasmodial activity was found in the extracts of Chrozophora oblongifolia, Ficus ingens, Lavandula dentata and Plectranthus barbatus. Amastigotes of T. cruzi were affected by Grewia erythraea, L. dentata, Tagetes minuta and Vernonia leopoldii. Activity against T. brucei was obtained in G. erythraea, L. dentata, P. barbatus and T. minuta. No relevant activity was found against $L$. infantum. High levels of cytotoxicity (MRC-5 IC ${ }_{50}<10 \mu \mathrm{g} / \mathrm{ml}$ ) and hence non-specific activities were noted in Cupressus sempervirens, Kanahia laniflora and Kniphofia sumarae.
\end{abstract}

Conclusion: The results endorse that medicinal plants can be promising sources of natural products with antiprotozoal activity potential. The results support to some extent the traditional uses of some plants for the treatment of parasitic protozoal diseases.

\section{Background}

Today over one billion people worldwide are at risk for tropical diseases caused by parasitic organisms. The World Health Organization (WHO) now classifies many as neglected tropical diseases, having an enormous impact on socioeconomic development and quality of life at all levels particularly in developing countries [1]. At present, a lot of research is committed to leishmaniasis, malaria, Chagas disease and sleeping sickness, not only because they are major killing diseases but also because disease control becomes more difficult due to a number of factors that limit the utility of current drugs in resource-poor settings,

\footnotetext{
*Correspondence: rmothana@ksu.edu.sa; r_mothana@yahoo.com

'Department of Pharmacognosy, College of Pharmacy, King Saud University, P.O. Box 2457, Riyadh 11451, Saudi Arabia

Full list of author information is available at the end of the article
}

such as high cost, poor compliance, drug resistance, low efficacy and poor safety [2]. Hence, the search for new and preferably cheap drugs needs to be continued [3].

Natural products are still major potential sources of innovative therapeutic agents for various conditions, including infectious diseases as they represent an unmet source of chemical diversity [4]. Indeed, several antiparasitic drugs have been derived directly from natural sources, such as quinine, artemisinin and atovaquone as antimalarials and amphotericin $B$ as antileishmanial drug.

It is estimated that two thirds of the world population still rely on traditional medical remedies, mainly plants, because of limited availability and affordability of pharmaceutical medicines [5]. This explains why a lot of current research focuses on natural molecules and plant-derived products as they can be sourced easily, are locally available 
and can be selected on the basis of their ethnomedicinal use [6].

In this study, 25 plants were selected from the flora of Yemen and Saudi Arabia, and subjected to a broad panel of in vitro antiparasitic assays in an attempt to identify plant species with a promising antiprotozoal in vitro activity profile and could be subject for further investigations.

\section{Methods}

\section{Plant materials}

Twenty five plants (Table 1) were selected randomly from different areas of Yemen and Saudi Arabia in March and Jun 2008 and identified at the Pharmacognosy Departments, Colleges of Pharmacy, King Saud and Sana'a Universities, Saudi Arabia and Yemen. The plants were selected mainly on the basis of their local medicinal

Table 1 List of plants screened and their traditional uses

\begin{tabular}{|c|c|c|c|c|}
\hline Plant species & $\begin{array}{l}\text { Voucher } \\
\text { specimen no. }\end{array}$ & Family & $\begin{array}{l}\text { Part } \\
\text { used }\end{array}$ & Traditional uses \\
\hline Ajuga bracteosa Wall. ex Benth. & Mo-I10a & Labiatae & $L, F$ & $\begin{array}{l}\text { As antiseptic and for teeth pains, stimulant, diuretic and in treatment of } \\
\text { rheumatism, gout, palsy, amenorrhea and malaria } a, b\end{array}$ \\
\hline $\begin{array}{l}\text { Caralluma quadrangula (Forssk.) } \\
\text { N.E.Br. }\end{array}$ & Mo-H02a & Asclepiadaceae & L & For diabetes, stomachic ulcer and smallpox ${ }^{a, c}$ \\
\hline Centaurea pseudosinaica Czerep. & Mo-S11a & Asteraceae & $L, T$ & For wounds and kidney diseases ${ }^{a}$ \\
\hline $\begin{array}{l}\text { Chrozophora oblongifolia (Del.) } \\
\text { A.Juss. ex Spreng. }\end{array}$ & Mo-S02a & Euphorbiacea & $L, S$ & $\begin{array}{l}\text { As antiseptic for wounds, antimicrobial, cathartic, emetic and hypoglycemic } \\
\text { and for hemorrhoids a, d }\end{array}$ \\
\hline Costus arabicus $\mathrm{L}$. & Mo-S05a & Zingiberaceae & $\mathrm{R}$ & For cancers $^{\mathrm{a}}$ \\
\hline Cupressus sempervirens L. & Mo-S25a & Cupressaceae & L & As expectorant, astringent and for wounds, diarrhea, hemorrhoids ${ }^{a, c}$ \\
\hline Dodonaea viscosa (L.) Jacq. & Mo-T01a & Sapindaceae & $L, S$ & $\begin{array}{l}\text { For malaria, wounds and burns, gout, rheumatism and as anesthetic, } \\
\text { laxative and tonic }{ }^{a, c, e, f,}\end{array}$ \\
\hline Dorstenia barnimiana Schweinf. & Mo-T09 & Moraceae & $L, S$ & For the treatment of fungal and skin diseases ${ }^{a, c}$ \\
\hline $\begin{array}{l}\text { Enicostemma verticillare } \\
\text { (Retz.) Baill. }\end{array}$ & Mo-106a & Gentianaceae & L & For diabetes $^{\text {a }}$ \\
\hline Ficus cordata ssp. Salicifolia & 15133 & Moraceae & $L, S$ & $\begin{array}{l}\text { For the treatment of filariasis, diarrheal infections, tuberculosis and oral } \\
\text { infections }^{\text {a, } c}\end{array}$ \\
\hline Ficus ingens (Miq.) & 15187 & Moraceae & $L, S$ & For Piles, diarrhea, and as diuretic ${ }^{\text {a }}$ \\
\hline Ficus palmata Forssk & 15163 & Moraceae & $L, S$ & For constipation and lungs and bladder diseases ${ }^{a, c}$ \\
\hline Grewia erythraea Schweinf. & Mo-S07a & Tiliaceae & $L, S$ & As Diuretic and haemostatic and for kidney diseases ${ }^{a}$ \\
\hline Iris albicans Lange & Mo-102a & Iridaceae & $\mathrm{R}$ & For rheumatism and gout ${ }^{a}$ \\
\hline Kanahia laniflora (Forsk.) R. Br. & Mo-119a & Asclepiadaceae & $L, T$ & For tumors, skin diseases, scabies and itching ${ }^{a, c, ~ h}$ \\
\hline Kniphofia sumarae Deflers & Mo-I10a & Liliaceae & $\mathrm{R}$ & For malaria ${ }^{a}$ \\
\hline Lavandula dentata $\mathrm{L}$. & Mo-111a & Labiatae & $L, F$ & $\begin{array}{l}\text { For wounds, rheumatism, urine retention, and kidney stones and as } \\
\text { antiseptic }^{\text {a, }} \text { d }\end{array}$ \\
\hline Leucas inflata Benth. & Mo-105a & Labiatae & $L, F$ & For kidney diseases and tooth ache ${ }^{a}$ \\
\hline Pulicaria inuloides DC. & Mo-M05a & Asteraceae & $L, F$ & For wounds and as antiseptic ${ }^{a}$ \\
\hline Plectranthus barbatus Andr. & $15732 \mathrm{a}$ & Labiatae & $L, S$ & $\begin{array}{l}\text { For stomachache, nausea, gastritis, intestinal spasms, burns, wounds, sores, } \\
\text { insect bites, allergies, ringworms, infections, malaria and break fevers }{ }^{a} \text {, }\end{array}$ \\
\hline Rhus retinorrhaea Steud. ex Oliv. & Mo-T22a & Anacardiaceae & L & General tonic and for painful joints ${ }^{a}$ \\
\hline Tagetes minuta L. & YT-20a & Asteraceae & $L, S$ & As antimicrobial, anthelmintic, diuretic, and antispasmodic agent ${ }^{a, f}$ \\
\hline Tarconanthus camphoratus $L$ & Mo-S15a & Asteraceae & $L, T$ & For wounds and for urinary tract infections ${ }^{a}$ \\
\hline Teucrium yemense Deflers & Mo-S17a & Labiatae & $L, F$ & For kidney diseases, rheumatism and diabetes ${ }^{a, d}$ \\
\hline Vernonia leopoldii Vatke & Mo-T16a & Asteraceae & $L, F$ & For cough, colic and skin diseases ${ }^{\mathrm{a}, \mathrm{h}}$ \\
\hline
\end{tabular}

$F$ Flower, $L$ Leaves, $R$ Roots or rhizomes, $S$ Stems, $T$ Fruits.

a information has been taken from native people.

${ }^{b}$ Chandel S, Bagai U, 2010 [7].

c Al-Dubai and Al-Khulaidi (1996) [8].

d Atiqur-Rahman et al., (2004) [9].

e Mossa et al., (1987) [10].

${ }^{f}$ Ali et al., (2004) [11].

${ }^{9}$ Fleurentin and Pelt (1982) [12].

${ }^{\mathrm{h}}$ Schopen (1983) [13]. 
knowledge. Voucher specimens were deposited at departments. The botanical names, plant part used and the traditional uses of the plants in the collected areas are presented in Table 1.

\section{Extraction of plant materials}

The air-dried and powdered plant material $(50 \mathrm{~g})$ was extracted with $500 \mathrm{ml}$ methanol $\left(\mathrm{CH}_{3} \mathrm{OH}\right)$ by using a Soxhlet apparatus for 8 hours. The obtained methanol extract was filtered and evaporated by using a rotatory evaporator and freeze dryer. The dried extracts were stored at $-20^{\circ} \mathrm{C}$ until used. Stock solutions were prepared in 100\% DMSO at $20 \mathrm{mg} / \mathrm{ml}$ just prior to screening.

\section{Reference drugs}

For the different tests, appropriate reference drugs were used as positive control: tamoxifen for MRC-5, chloroquine for $P$. falciparum, miltefosine for L. infantum, benznidazole for $T$. cruzi and suramin for $T$. b. brucei. All reference drugs were either obtained from the fine chemical supplier Sigma or from WHO-TDR.

\section{Biological assays}

The integrated panel of microbial screens and standard screening methodologies were adopted as previously described [14]. All assays were performed in triplicate (first test in duplicate and a single independent repeat) at the Laboratory of Microbiology, Parasitology and Hygiene at the University of Antwerp, Belgium. Plant extracts were tested at 5 concentrations $(64,16,4,1$ and $0.25 \mu \mathrm{g} / \mathrm{ml}$ ) to establish a full dose-titration and determination of the $\mathrm{IC}_{50}$ (inhibitory concentration 50\%). The concentration of DMSO did not exceed $0.5 \%$. The selectivity of action was assessed by simultaneous evaluation of cytotoxicity on a fibroblast (MRC-5) cell line. The criterion for activity was an $\mathrm{IC}_{50}<10 \mu \mathrm{g} / \mathrm{ml}(<5 \mu \mathrm{g} / \mathrm{ml}$ for T. brucei) and a selectivity index of $\geq 4$.

\section{Antileishmanial activity}

L.infantum MHOM/MA(BE)/67 amastigotes were collected from the spleen of an infected donor hamster and used to infect primary peritoneal mouse macrophages. To determine in vitro antileishmanial activity, $3 \times 10^{4}$ macrophages were seeded in each well of a 96-well plate. After 2 days outgrowth, $5 \times 10^{5}$ amastigotes/well were added and incubated for $2 \mathrm{~h}$ at $37^{\circ} \mathrm{C}$. Pre-diluted plant extracts were subsequently added and the plates were further incubated for 5 days at $37^{\circ} \mathrm{C}$ and $5 \% \mathrm{CO}_{2}$. Parasite burdens (mean number of amastigotes/macrophage) were microscopically assessed after Giemsa staining, and expressed as a percentage of the blank controls without plant extract.

\section{Antiplasmodial activity}

Chloroquine-resistant $P$. falciparum $2 / \mathrm{K}$ 1-strain was cultured in human erythrocytes $\mathrm{O}^{+}$at $37^{\circ} \mathrm{C}$ under a low oxygen atmosphere $\left(3 \% \mathrm{O}_{2}, 4 \% \mathrm{CO}_{2}\right.$, and $\left.93 \% \mathrm{~N}_{2}\right)$ in RPMI-1640, supplemented with $10 \%$ human serum. Infected human red blood cells (200 $\mu$ l, 1\% parasitaemia, 2\% haematocrit) were added to each well and incubated for $72 \mathrm{~h}$. After incubation, test plates were frozen at $-20^{\circ} \mathrm{C}$. Parasite multiplication was measured by the Malstat method [14,15].

\section{Antitrypanosomal activity}

Trypanosoma brucei Squib-427 strain (suramin-sensitive) was cultured at $37^{\circ} \mathrm{C}$ and $5 \% \mathrm{CO}_{2}$ in Hirumi-9 medium [16], supplemented with $10 \%$ fetal calf serum (FCS). About $1.5 \times 10^{4}$ trypomastigotes/well were added to each well and parasite growth was assessed after $72 \mathrm{~h}$ at $37^{\circ} \mathrm{C}$ by adding resazurin [17]. For Chagas disease, $T$. cruzi Tulahuen CL2 (benznidazole-sensitive) was maintained on MRC-5 cells in minimal essential medium (MEM) supplemented with $20 \mathrm{mM}$ L-glutamine, $16.5 \mathrm{mM}$ sodium hydrogen carbonate and $5 \%$ FCS. In the assay, $4 \times 10^{3}$ MRC-5 cells and $4 \times 10^{4}$ parasites were added to each well and after incubation at $37^{\circ} \mathrm{C}$ for 7 days, parasite growth was assessed by adding the $\beta$-galactosidase substrate chlorophenol red $\beta$-D-galactopyranoside [18]. The color reaction was read at $540 \mathrm{~nm}$ after $4 \mathrm{~h}$ and absorbance values were expressed as a percentage of the blank controls.

\section{Cytotoxicity assay}

MRC-5 SV2 cells were cultivated in MEM, supplemented with L-glutamine (20 mM), $16.5 \mathrm{mM}$ sodium hydrogen carbonate and 5\% FCS. For the assay, $10^{4}$ MRC-5 cells/well were seeded onto the test plates containing the pre-diluted sample and incubated at $37^{\circ} \mathrm{C}$ and $5 \% \mathrm{CO}_{2}$ for $72 \mathrm{~h}$. Cell viability was assessed fluorimetrically after 4 hours of addition of resazurin. Fluorescence was measured (excitation $550 \mathrm{~nm}$, emission $590 \mathrm{~nm}$ ) and the results were expressed as \% reduction in cell viability compared to control.

\section{Results}

Crude methanol extracts from 25 plant species belonging to 18 families that are used in Arabian traditional medicine, were evaluated in the integrated in vitro screen for antileishmanial, antiplasmodial and antitrypanosomal potential (Table 2). Only 7 extracts exhibited relevant activity (acceptable potency and selectivity) in one or more models (Table 2).

\section{Antimalarial activity}

In this study, the methanol extract of Chrozophora oblongifolia exhibited the greatest activity against $P$. falciparum with an $\mathrm{IC}_{50}$ value of $5.0 \mu \mathrm{g} / \mathrm{ml}$ and a high SI value of 12.8 . Furthermore, the extract of three other plants (Ficus ingens, 
Table 2 Antiprotozoal activity of the methanol extracts of the investigated plants and their cytotoxicity against MRC-5 cell lines

\begin{tabular}{|c|c|c|c|c|c|c|c|c|c|}
\hline \multirow[t]{2}{*}{ Plant species } & \multirow{2}{*}{$\frac{P . \text { falciparum }}{\mathrm{IC}_{50}}$} & \multirow[b]{2}{*}{ SI } & \multirow{2}{*}{$\frac{\text { L. infantum }}{\mathrm{IC} \mathrm{C}_{50}}$} & \multirow[b]{2}{*}{ SI } & \multirow{2}{*}{$\frac{T . \text { cruzi }}{\mid C_{50}(\mu \mathrm{g} / \mathrm{ml})}$} & \multirow[b]{2}{*}{ SI } & \multirow{2}{*}{$\frac{\text { T. brucei }}{\mathrm{IC}_{50}}$} & \multirow[b]{2}{*}{ SI } & \multirow{2}{*}{$\frac{M R C-5}{I C_{50}}$} \\
\hline & & & & & & & & & \\
\hline Ajuga bracteosa & $>64.0$ & $>1$ & $>64.0$ & $>1$ & $28.8 \pm 4.6$ & $>2.22$ & $31.2 \pm 5.2$ & $>2.05$ & $>64.0$ \\
\hline Caralluma quadrangula & $27.5 \pm 4.3$ & $>2.33$ & $>64.0$ & $>1$ & $>64.0$ & $>1$ & $32.5 \pm 6.5$ & $>1.97$ & $>64.0$ \\
\hline Centaurea pseudosinaica & $48.2 \pm 9.8$ & & $32.5 \pm 3.5$ & & $31.0 \pm 6.1$ & & $9.1 \pm 1.8$ & 1.76 & $16.0 \pm 5.3$ \\
\hline Chrozophora oblongifolia & $5.0 \pm 1.2$ & 12.80 & $27.3 \pm 2.8$ & 2.34 & $32.0 \pm 5.8$ & $>2$ & $10.8 \pm 2.4$ & 5.93 & $>64.0$ \\
\hline Costus arabicus & $>64.0$ & & $27.3 \pm 3.1$ & 1.41 & $13.8 \pm 2.1$ & 2.79 & $30.0 \pm 4.9$ & 1.28 & $38.5 \pm 8.2$ \\
\hline Cupressus sempervirens & $7.6 \pm 2.4$ & 1.41 & $2.0 \pm 0.4$ & 5.35 & $8.3 \pm 1.9$ & 1.29 & $2.1 \pm 0.2$ & 5.10 & $10.7 \pm 3.1$ \\
\hline Dorstenia barnimiana & $34.2 \pm 8.7$ & 1.44 & $>64.0$ & & $29.6 \pm 3.9$ & 1.67 & $22.6 \pm 5.8$ & 2.19 & $49.4 \pm 9.1$ \\
\hline Dodonaea viscosa & $46.7 \pm 11.8$ & $>1.37$ & $45.3 \pm 11.8$ & 1.41 & $>64.0$ & $>1$ & $11.1 \pm 1.8$ & 5.77 & $>64.0$ \\
\hline Enicostemma verticillare & $>64.0 \pm$ & $>1$ & $>64.0$ & $>1$ & $>64.0$ & $>1$ & $9.9 \pm 1.1$ & $>6.46$ & $>64.0$ \\
\hline Ficus cordata ssp.salicifolia & $27.0 \pm 6.9$ & 1.20 & $27.3 \pm 6.1$ & 1.19 & $26.3 \pm 3.2$ & 1.24 & $8.2 \pm 1.9$ & 3.96 & $32.5 \pm 7.3$ \\
\hline Ficus ingens & $8.4 \pm 2.3$ & 3.87 & $32.5 \pm 7.2$ & 1.00 & $31.2 \pm 4.3$ & 1.04 & $8.0 \pm 2.2$ & 4.06 & $32.5 \pm 7.5$ \\
\hline Ficus palmata & $14.5 \pm 3.8$ & 2.60 & $>64.0$ & & $22.6 \pm 4.0$ & 1.67 & $8.1 \pm 2.6$ & 4.65 & $37.7 \pm 6.9$ \\
\hline Grewia erythraea & $11.7 \pm 3.5$ & 2.32 & $24.1 \pm 3.8$ & 1.13 & $8.2 \pm 1.8$ & 3.32 & $2.6 \pm 0.9$ & 10.46 & $27.2 \pm 6.1$ \\
\hline Iris albicans & $55.5 \pm 6.2$ & $>1.15$ & $>64.0$ & $>1$ & $>64.0$ & $>1$ & $10.6 \pm 3.1$ & $>6.04$ & $>64.0$ \\
\hline Kanahia laniflora & $27.9 \pm 4.9$ & & $>64.0$ & & $0.4 \pm 0.2$ & 2.00 & $9.6 \pm 3.0$ & & $0.8 \pm 0.2$ \\
\hline Kniphofia sumarae & $1.3 \pm 0.6$ & 5.69 & $32.5 \pm 4.9$ & & $31.4 \pm 3.4$ & & $5.9 \pm 2.8$ & 1.25 & $7.4 \pm 1.4$ \\
\hline Lavandula dentata & $7.1 \pm 1.4$ & 4.17 & $20.3 \pm 3.5$ & 1.46 & $7.9 \pm 0.5$ & 3.75 & $3.0 \pm 1.8$ & 9.87 & $29.6 \pm 5.9$ \\
\hline Leucas inflata & $44.6 \pm 6.3$ & & $>64.0$ & & $>64.0$ & & $8.4 \pm 2.2$ & 3.51 & $29.5 \pm 6.0$ \\
\hline Plectranthus barbatus & $6.5 \pm 2.0$ & 5.06 & $24.1 \pm 2.9$ & 1.37 & $23.3 \pm 2.9$ & 1.41 & $2.6 \pm 1.8$ & 12.65 & $32.9 \pm 6.8$ \\
\hline Pulicaria inuloides & $21.6 \pm 3.8$ & $>2.96$ & $45.3 \pm 8.3$ & 1.41 & $31.7 \pm 4.0$ & $>2.02$ & $7.8 \pm 2.1$ & $>8.21$ & $>64.0$ \\
\hline Rhus retinorrhaea & $37.1 \pm 4.9$ & 1.43 & $>64.0$ & & $30.5 \pm 3.9$ & 1.74 & $34.0 \pm 5.8$ & 1.56 & $53.2 \pm 7.2$ \\
\hline Tagetes minuta & $14.0 \pm 2.8$ & 4.57 & $30.1 \pm 4.6$ & $>2.13$ & $9.2 \pm 1.9$ & $>6.96$ & $2.2 \pm 1.5$ & $>29.09$ & $>64.0$ \\
\hline Tarconanthus camphoratus & $>64.0$ & $>1$ & $>64.0$ & $>1$ & $>64.0$ & $>1$ & $>64.0$ & $>1$ & $>64.0$ \\
\hline Teucrium yemense & $12.5 \pm 2.6$ & 2.18 & $32.5 \pm 6.6$ & & $30.5 \pm 2.9$ & & $7.1 \pm 2.3$ & 3.83 & $27.2 \pm 5.3$ \\
\hline Vernonia leopoldii & $41.9 \pm 7.9$ & & $27.3 \pm 5.1$ & 1.10 & $9.2 \pm 1.2$ & 3.27 & $8.0 \pm 2.9$ & 3.76 & $30.1 \pm 4.9$ \\
\hline Chloroquine & $0.3 \pm 0.1$ & & - & & - & & - & & - \\
\hline Miltefosine & - & & $3.32 \pm 0.7$ & & - & & - & & - \\
\hline Benznidazole & - & & - & & $2.2 \pm 0.5$ & & - & & - \\
\hline Suramin & - & & - & & - & & $0.03 \pm 0.02$ & & - \\
\hline Tamoxifen & - & & - & & - & & - & & $11.0 \pm 2.3$ \\
\hline
\end{tabular}

$\mathrm{IC}_{50}$ values of reference drugs are expressed in $\mu \mathrm{M} / \mathrm{ml}$ concentrations.

Lavandula dentata and Plectranthus barbatus) showed activity against $P$. falciparum with $\mathrm{IC}_{50} 8.4,7.1$ and $6.5 \mu \mathrm{g} / \mathrm{ml}$ respectively. These extracts exhibited moderate SI values of $3.8,4.1$ and 5.1, respectively.

\section{Antileishmanial activity}

No relevant results were found against L. infantum. A very marginal activity was observed for C. oblongifolia, Costus arabicus, Grewia erythraea, L. dentata, P. barbatus, and Vernonia leopoldii with $\mathrm{IC}_{50}$ values between 20.3 and $27.3 \mu \mathrm{g} / \mathrm{ml}$ and low SI values between 1.0 and 2.5.

\section{Antitrypanosomal activity}

Our screen demonstrated that $T . b$. brucei is more sensitive than T. cruzi towards the investigated plant extracts (Table 2). The results revealed that the extract of G. erythraea showed activity against $T$. cruzi $\left(\mathrm{IC}_{50} 8.2 \mu \mathrm{g} / \mathrm{ml}\right)$ and $T$. brucei ( $\mathrm{IC}_{50} 2.6 \mu \mathrm{g} / \mathrm{ml}$ ). Additionally, L. dentata demonstrated activity against $T$. cruzi and $T$. brucei with $\mathrm{IC}_{50}$ values of 7.9 and $3.0 \mu \mathrm{g} / \mathrm{ml}$ respectively. Meanwhile, the extract of Tagetes minuta showed less activity against $T$. cruzi with an $\mathrm{IC}_{50}$ value of $9.2(\mathrm{SI}=6.9)$ and higher activity against T. brucei with an $\mathrm{IC}_{50}$ value of $2.2 \mu \mathrm{g} / \mathrm{ml}$ and the highest SI value of $>29.1$. On the other hand, the methanol extract of $P$. barbatus, showed antitrypanosomal activity only 
against $T$. brucei $\left(\mathrm{IC}_{50} 2.6 \mu \mathrm{g} / \mathrm{ml}\right)$ with high SI value of 12.6 , while the extract of $V$. leopoldii showed activity against both T. cruzi and T. brucei ( $\mathrm{IC}_{50} 9.2$ and $\left.8.0 \mu \mathrm{g} / \mathrm{ml}\right)$ with low SI values of 3.2 and 3.7 respectively.

\section{Cytotoxicity assay}

The highest cytotoxic effect against MRC-5 cells was obtained with the methanol extract of Kanahia laniflora $\left(\mathrm{IC}_{50}\right.$ of $\left.0.83 \mu \mathrm{g} / \mathrm{ml}\right)$. The extracts of Kniphofia sumarae and Cupressus sempervirens also exhibited a noticeable cytotoxic effect with $\mathrm{IC}_{50}$ values of 7.7 and $10.7 \mu \mathrm{g} / \mathrm{ml}$ respectively (Table 2 ).

\section{Discussion}

The scientific evaluation of medicinal plants used in the preparation of folk remedies has provided modern medicine with several effective pharmaceuticals for the treatment of diseases caused by protozoan parasites $[19,20]$. As a result of this, during the last two decades numerous studies from various parts of the world on antiprotozoal activity of medicinal plants have been reported [21-26].

In continuation of our search for substances of plant origin with pharmacological effects, we have screened 25 plants collected from Saudi Arabia and Yemen for their antiplasmodial, antileishmanial and antitrypanosomal activities. It is important to mention that at the best of our knowledge, this study represents the first report on antiprotozoal activities for most part of the investigated plants. Although few plants are partly investigated, existing knowledge remains in many cases very limited. Based on the activity $\left(\mathrm{IC}_{50}\right)$ and selectivity, seven plant extracts could be considered as promising and interesting enough to engage in further purification and evaluation.

During the course of screening, it was found that the methanol extract of the $C$. oblongifolia, collected from Yemen, exhibited the greatest antiplasmodial activity. Our result is in agreement with data reported recently by Abdel-Sattar et al. (2010) [27], which showed antiplasmodial activity for this species collected from Saudi Arabia $\left(\mathrm{IC}_{50} 4.8 \mu \mathrm{g} / \mathrm{ml}\right)$ with a better selectivity (SI > 13.2). Moreover, Benoit-Vical et al. (2008) [28] reported that the water extract of Chrozophora senegalensis showed a remarkable in vitro antimalarial activity $\left(\mathrm{IC}_{50} 1.6 \mu \mathrm{g} / \mathrm{ml}\right)$.

Other interesting and promising source of antiplasmodial and antitrypanosomal activities is F. ingens. It is worth to mention that this is the first report on the antiprotozoal activity of $F$. ingens. Other Ficus species like F. citrifolia, F. fistulosa, and F. sur demonstrated a noticeable antimalarial activity [29-31]. Moreover, bioassay-guided fractionation of the extract from the dried leaves and stem barks of $F$. fistulosa led to the isolation of trichothecene sesquiterpenoids, including verrucarin $\mathrm{L}$ acetate which was found to inhibit the growth of $P$. falciparum with $\mathrm{IC}_{50}$ values below $1 \mathrm{ng} / \mathrm{ml}$ [30].
Another interesting plant was G. erythraea, which demonstrated considerable antimalarial and antitrypanosomal activities. Our data are in agreement with literature data of other Grewia species such as G. hexaminta and G. bilamellata [32,33]. Ma et al., (2006) [32] demonstrated that some triterpenoids e.g. $3 \alpha, 20$-lupandiol, grewin, nitidanin and $2 \alpha, 3 \beta$-dihydroxy-olean-12-en-28-oic acid isolated from $G$. bilamellata are responsible for the antimalarial effect and showed varying degrees of in vitro activity against $P$. falciparum. The presence of such terpenoids in our G. erythraea may explain the biological effects seen in our screen.

Moreover, one of the most interesting plants was $L$. dentata collected from Yemen. Our antiparasitic screening revealed remarkable in vitro antiplasmodial and antitrypanosomal activity observed for L. dentata but with moderate SI of 4.1 and 9.8. These findings are in agreement with literature data published recently by Abdel-Sattar et al. (2010) [27] who reported the antiparasitic activity of the methanol extract of $L$. dentata growing in Saudi Arabia. The extract of L. dentata growing in Saudi Arabia showed better selectivity for $P$. falciparum $(\mathrm{SI}=32.1)$ as compared with our results. This can be attributed to variation in the area of collection and ecological factors, which has a great impact on the quality and quantity of plants constituents. Apparently the activity of this species is mostly attributed to the presence of essential oil which was revealed to be responsible for antiparasitic and antibacterial activities [34,35].

Tempone et al., (2008) [36] investigated the antileishmanial activity of some Brazilian flora extracts, including $P$. barbatus which showed activity against $L$. chagasi with $\mathrm{EC}_{50}$ value of $54.5 \mu \mathrm{g} / \mathrm{ml}$. In earlier studies, several Plectranthus species showed antiplasmodial activity against P. falciparum 3D7 strain $[37,38]$. The results obtained in the present screen are in agreement with the literature data found and hence justifies the folkloric use. In addition to that, Van Zyl et al., (2008) [38] attributed the antiplasmodial activity of these Plectranthus species to the presence of abietane diterpenes.

Whereas the crude extract of $T$. minuta showed a remarkable antitrypanosomal activity against both trypanosome species, no effect was found against P. falciparum. Obviously our results of the antiplasmodial activity of T. minuta were not in agreement with the antimalarial effect noted recently by Lacroix et al., (2011) and Shahzadi et al., (2010) [39,40]. It was demonstrated that the ethyl acetate as well as $n$-hexane extract exhibited a notable antimalarial activity at $2.78 \mu \mathrm{g} / \mathrm{ml}$ against $P$. falciparum 3D7 strain. Apparently these findings are attributed to the presence of essential oil as well as sesquiterpene lactones.

In our screen $A$. bracteosa didn't show any interesting antiprotozoal activity. These results are not in agreement with those recently reported by Chandel and Bagai (2010) [7]. In contrast to several reports on Vernonia 
species e.g. $V$. amygdalina, $V$. brachycalyx., $V$. cinerea and $V$. colorata indicating in vitro and in vivo antiplasmodial activity [41-43], our extract of $V$. leopoldii showed no antiplsmodial activity. On the other hand, $V$. leopoldii showed a notable antitrypanosomal activity, which was in agreement with the results obtained by Hoet et al. (2004) [44] who attributed the antitrypanosomal activity to the presence of stigmastane-type steroids e.g. vernoguinosterol and vernoguinoside, which were isolated from the stem bark of $V$. guineensis. Such compounds could also be responsible for the observed effect of $V$. leopoldii.

\section{Conclusion}

In conclusion, the results show that scientific studies carried out on medicinal plants having traditional claims of effectiveness can yield fruitful results. The present work led to the identification of seven plant extracts exhibiting relevant antiprotozoal potential namely $C$. oblongifolia, F. ingens, G. erythraea, L. dentata, P. barbatus, T. minuta and $V$. leopoldii. Moreover, the results in the present study support to some extent the traditional uses of some plants for the treatment of parasitic diseases. Studies aimed at the isolation and structure elucidation of antiprotozoal active constituents from some investigated plants are now in progress.

\section{Competing interests}

The author(s) declare that they have no competing interests.

\section{Authors' contributions}

RAM and NMA carried out the study design, plant collection and extraction, part of the experimental work, data collection and interpretation, literature search and manuscript preparation. AM carried out the in vitro assays, PC and LM evaluated the data and corrected the manuscript for publication. All authors read and approved the final manuscript.

\section{Acknowledgements}

The authors extend their appreciation to the NPST program by King Saud University for funding the work through the project number (10-MED128802). The authors gratefully acknowledge that financial support.

\section{Author details}

'Department of Pharmacognosy, College of Pharmacy, King Saud University, P.O. Box 2457, Riyadh 11451, Saudi Arabia. '2Laboratory for Microbiology, Parasitology and Hygiene (LMPH), Faculty of Pharmaceutical, Biomedical and Veterinary Sciences, Antwerp University, Universiteitsplein 1, 2610, Wilrijk-Antwerp, Belgium.

Received: 21 December 2011 Accepted: 13 April 2012 Published: 20 April 2012

\section{References}

1. World Health Organization: Working to overcome the global impact of neglected tropical diseases: First WHO report on neglected tropical diseases. No. 1; 2010.

2. Nwaka S, Ridley RG: Virtual drug discovery and development for neglected diseases through public private partnerships. Nat Rev Drug Discov 2003, 2:919-928.

3. Nwaka S, Hudson A: Innovative lead discovery strategies for tropical diseases. Nat Rev Drug Discov 2006, 5:941-955.

4. Clardy J, Walsh C: Lessons from natural molecules. Nature 2004, 432:829-837.

5. Tagboto S, Townson S: Antiparasitic properties of medicinal plants and other naturally occurring products. Adv Parasitol 2001, 50:199-295.
6. Verpoorte R, Choi YH, Kim HK: Ethnopharmacology and systems biology: A perfect holistic match. J Ethnopharmacol 2005, 100:53-56.

7. Chandel S, Bagai U: Antiplasmodial activity of Ajuga bracteosa against Plasmodium berghei infected BALB/c mice. Indian J Med Res 2010, 131:440-444.

8. Al-Dubai AS, Al-khulaidi AA: Medicinal and Aromatic Plants of Yemen (In Arabic). Sana'a, Yemen: Obadi Center for studies and Publishing; 1996.

9. Atiqur-Rahman M, Mossa JS, Al-Said MS, Al-Yahya MA: Medicinal Plant Diversity in the Flora of Saudi Arabia 1: a Report on Seven Plant Families. Fitoterapia 2004, 75:149-161.

10. Mossa JS, Al-Yahya MA: Al-Meshal I A: Medicinal Plants of Saudi Arabia. Riyadh, Saudi Arabia: King Saud University; 1987.

11. Ali AA, Al-rahwi K, Lindequist U: Some Medicinal Plants Used in Yemeni Herbal Medicine to Treat Malaria. Afr J Trad Complement Altern Med 2004, 1:72-76.

12. Fleurentin J, Pelt JM: Repertory of drugs and medicinal plants of Yemen. J Ethnopharmacol 1982, 6:85-108.

13. Schopen A: Traditionelle Heilmittel in Jemen. Berlin: Franz Steiner Verlag $\mathrm{GmbH} ; 1983$.

14. $\operatorname{Cos} P$, Vlietinck AJ, Berghe DV, Maes L: Anti-infective potential of natural products: How to develop a stronger in vitro proof-of-concept. J Ethnopharmacol 2006, 106:290-302.

15. Makler MT, Ries JM, Williams JA, Bancroft JE, Piper RC, Hinrichs DJ: Parasite lactate dehydrogenase as an assay for Plasmodium falciparum drug sensitivity. Am J Trop Med Hyg 1993, 48:739-741.

16. Hirumi H, Hirumi K: Continuous cultivation of Trypanosoma brucei blood stream forms in a medium containing a low concentration of serum protein without feeder cell layers. J Parasitol 1989, 75:985-989.

17. Raz B, Iten M, Grether-Buhler Y, Kaminsky R, Brun R: The Alamar Blue asssay to determine drug sensitivity of African trypanosomes ( $T$. b. rhodesiense, T. b. gambiense) in vitro. Acta Trop 1997, 68:2592-2597.

18. Buckner FS, Verlinde CL, La Flamme AC, Van Voorhis WC: Efficient technique for screening drugs for activity against Trypanosoma cruzi using parasites expressing beta-galactosidase. Antimicrob Agents Chemother 1996, 40:2592-2597.

19. Phillipson JD, Wright CW: Antiprotozoal agents from plant sources. Planta Med 1991, 57:53-59.

20. Chan-Bacab MJ, Peña-Rodríguez LM: Plant natural products with leishmanicidal activity. Nat Prod Rep 2001, 18:674-688.

21. Maes L, Germonprez N, Quirijnen L, Van Puyvelde L, Cos P, Vanden Berghe D: Comparative activities of the triterpene saponin Maesabalide-III and liposomal amphotericin-B (AmBisome) against Leishmania donovani in hamsters. Antimicrob Agents Chemother 2004, 48:2056-2060.

22. Rocha LG, Almeida JRGS, Macêdo RO, Barbosa-Filho JM: A review of natural products with antileishmanial activity. Phytomedicine 2005, 12:514-535.

23. Chianese G, Yerbanga SR, Lucantoni L, Habluetzel A, Basilico N, Taramelli D, Fattorusso E, Taglialatela-Scafati O: Antiplasmodial triterpenoids from the fruits of neem, Azadirachta indica. J Nat Prod 2010, 73:1448-1452.

24. García M, Monzote L, Montalvo AM, Scull R: Screening of medicinal plants against Leishmania amazonensis. Pharm Biol 2010, 48:1053-1058.

25. Wright CW: Recent developments in research on terrestrial plants used for the treatment of malaria. Nat Prod Rep 2010, 27:961-968.

26. Wube AA, Bucar F, Gibbons S, Asres K, Rattray L, Croft SL: Antiprotozoal activity of drimane and coloratane sesquiterpenes towards Trypanosoma brucei rhodesiense and Plasmodium falciparum in vitro. Phytother Res 2010, 24:1468-1472

27. Abdel-Sattar E, Maes L, Salama MM: In Vitro Activities of Plant Extracts from Saudi Arabia against Malaria, Leishmaniasis, Sleeping Sickness and Chagas Disease. Phytother Res 2010, 24:1322-1328.

28. Benoit-Vical F, Soh PN, Saléry M, Harguem L, Poupat C, Nongonierma R: Evaluation of Senegalese plants used in malaria treatment: focus on Chrozophora senegalensis. J Ethnopharmacol 2008, 28:43-48.

29. Antoun MD, Ramos Z, Vazques J, Oquendo I, Proctor GR, Gerena L, Franzblau SG: Evaluation of the flora of Puerto Rico for in vitro antiplasmodial and antimycobacterial activities. Phytother Res 2001, 15:638-642.

30. Zhang HJ, Tamez PA, Aydogmus Z, Tan GT, Saikawa Y, Hashimoto K, Nakata M, Hung NV, Xuan le T, Cuong NM, Soejarto DD, Pezzuto JM, Fong HH: Antimalarial agents from plants. III. Trichothecenes from Ficus fistulosa and Rhaphidophora decursiva. Planta Med 2002, 68:1088-1091.

31. Muregi FW, Chhabra SC, Njagi EN, Lang'at-Thoruwa CC, Njue WM, Orago AS, Omar SA, Ndiege IO: In vitro antiplasmodial activity of some plants used 
in Kisii, Kenya against malaria and their chloroquine potentiation effects. J Ethnopharmacol 2003, 84:235-239.

32. Ma C, Zhang HJ, Tan GT, Hung NV, Cuong NM, Soejarto DD, Fong HH: Antimalarial compounds from Grewia bilamellata. J Nat Prod 2006, 69:346-350

33. Nguta JM, Mbaria JM, Gakuya DW, Gathumbi PK, Kiama SG: Antimalarial herbal remedies of Msambweni, Kenya. J Ethnopharmacol 2010, 24: 424-432.

34. Moon T, Wilkinson JM, Cavanagh HM: Antiparasitic activity of two Lavandula essential oils against Giardia duodenalis, Trichomonas vaginalis and Hexamita inflata. Parasitol Res 2006, 99:722-728.

35. Mohamed SB, Eddine AD: Antibacterial activity of essential oils of some Algerian aromatic plants against multidrug resistant bacteria. J Essen Oil-Bear Plants 2010, 13:362-370.

36. Tempone AG, Sartorelli P, Teixeira D, Prado FO, Calixto IA, Lorenzi $H$ Melhem MS: Brazilian flora extracts as source of novel antileishmanial and antifungal compounds. Mem Inst Oswaldo Cruz 2008, 103:443-449.

37. Lukhoba CW, Simmonds MSJ, Paton AJ: Plectranthus: A review of ethnobotanical uses. J Ethnopharmacol 2006, 103:1-24.

38. Van Zyl RL, Khan F, Edwards TJ, Drewes SE: Antiplasmodial activities of some abietane diterpenes from the leaves of five Plectranthus species. S Afri J Sci 2008, 104:62-64.

39. Lacroix D, Prado S, Kamoga D, Kasenene J, Namukobe J, Krief S, Dumontet V, Mouray E, Bodo B, Brunois F: Antiplasmodial and cytotoxic activities of medicinal plants traditionally used in the village of Kiohima, Uganda. J Ethnopharmacol 2011, 133:850-855.

40. Shahzadi I, Hassan A, Khan UW, Shah MM: Evaluating biological activities of the seed extracts from Tagetes minuta L. found in Northern Pakistan. J Med Plants Res 2010, 4:2108-2112.

41. Clarkson C, Maharaj VJ, Crouch NR, Grace OM, Pillay P, Matsabisa MG Bhagwandin N, Smith PJ, Folb PI: In vitro antiplasmodial activity of medicinal plants native to or naturalised in South Africa. J Ethnopharmacol 2004, 92:177-191.

42. Pillay P, Maharaj VJ, Smith PJ: Investigating South African plants as a source of new antimalarial drugs. J Ethnopharmacol 2008, 119:438-454.

43. Magadula JJ, Erasto P: Bioactive natural products derived from the East African flora. Nat Prod Rep 2009, 26:1535-1554.

44. Hoet S, Opperdoes F, Brun R, Quetin-Leclercq J: Natural products active against African trypanosomes: a step towards new drugs. Nat Prod Rep 2004, 21:353-364.

doi:10.1186/1472-6882-12-49

Cite this article as: Al-Musayeib et al.: In vitro antiplasmodial, antileishmanial and antitrypanosomal activities of selected medicinal plants used in the traditional Arabian Peninsular region. BMC Complementary and Alternative Medicine 2012 12:49.

\section{Submit your next manuscript to BioMed Central and take full advantage of:}

- Convenient online submission

- Thorough peer review

- No space constraints or color figure charges

- Immediate publication on acceptance

- Inclusion in PubMed, CAS, Scopus and Google Scholar

- Research which is freely available for redistribution 